\title{
Hubungan antara Konformitas Teman Sebaya dengan Perencanaan Karir pada Siswa
}

\author{
Rahma Intan Amalia Mintarso., Sunawan., Suharso \\ Jurusan Bimbingan dan Konseling Fakultas Ilmu Pendidikan \\ Universitas Negeri Semarang, Indonesia \\ 1.mintars0@gmail.com., ${ }^{2}$ sunawan@mail.unnes.ac.id., \\ ${ }^{2}$ suharso.kons@gmail.com
}

\begin{abstract}
Abstrak
Tujuan dalam penelitian ini adalah guna membuktikan adanya hubungan konformitas teman sebaya dengan perencanaan karir pada siswa sekolah pertama. Jenis penelitian yang digunakan adalah metode survey, dengan teknik pengambilan sampel yang digunakan dalam penelitian ini adalah teknik cluster random sampling karena populasi yang diteliti oleh membagi populasi menjadi beberapa kelompok yang terpisah yang disebut sebagai cluster. Responden dalam penelitian ini adalah siswa kelas VIII dan IX SMP Negeri 3 Kota Magelang terdiri dari kelas VIII yang berjumlah dua kelas dengan siswa sebanyak 59 dan dua kelas dari kelas IX dengan jumlah 57 siswa, dengan jumlah total 116 siswa, melalui pengaruh peran teman sebaya siswa mampu menentukan arah perencanaan karirnya. Dengan demikian peran teman sebaya sangat membantu siswa dalam memilih karirnya meskipun banyak faktor lain yang mempengaruhi diri siswa dalam menentukan arah pemilihan karirnya.

Kata Kunci: Bimbingan dan Konseling; Perencanaan Karir; Konformitas Teman Sebaya
\end{abstract}

\begin{abstract}
The objective of this study is to prove the relation between peers conformity and career planning on students of junior high school. The type of research used is a survey method, bu using cluster random sampling in which the population that is used is divided into several groups called a cluster. The subject in this research is the $8^{\text {th }}$ and $9^{\text {th }}$ grader in SMP Negeri 3 Kota Magelang. There are 116 total of respondents, in which the $8^{\text {th }}$ grader consists of 59 students and the $9^{\text {th }}$ grader consists of 57 students. The result shows that the involvement of peers makes students capable to define their career planning. Thus, peers involvement helps students in choosing their career even though many other factors influence the students in defining their career.
\end{abstract}

Keyword : : Guidance and Counseling; Career Planning; Peer Conformity 


\section{Pendahuluan}

Masalah karir merupakan salah satu jenis permasalah yang sering dijumpai pada peserta didik. beberapa pertanyaan yang sering muncul, seperti bagaimana menyiapkan diri untuk masa depan, jenis pendidikan apa yang harus ditempuh untuk mencapai pekerjaan atau karir yang diinginkan, serta bagaimana cara untuk mencapai karir atau pekerjaan tersebut. Sejumlah pertanyaan ini menjadi permasalahan yang merisaukan peserta didik. Keadaan tersebut merupakan kesulitan-kesulitan yang dialami oleh peserta didik remaja dalam membuat perencanaan karirnya sehingga berpengaruh terhadap proses pengambilan keputusan karir nantinya. Glueck (1997) menyatakan bahwa karir individual adalah urutan pengalaman yang berkaitan dengan pekerjaan yang dialami seseorang selama masa kerjanya, sehingga karir individu melibatkan rangkaian pilihan dari berbagai kesempatan tapi dari sudut pandang organisasi karir yang merupakan proses regenerasi tugas yang baru.

Di sekolahan siswa tidak hanya dibekali dengan aspek kognitif tetapi juga aspek-aspek lainnya, termasuk aspek sosial. Tidak dipungkiri jika pengelompokan sosial remaja paling sering terjadi selama masa remaja dan bisa dimulai ketika menginjak kaki di Sekolah Menengah Pertama (SMP). Diantaranya pengelompokan sosial remaja ialah; Teman Dekat, Kelompok Kecil, Kelompok Besar, Kelompok yang Terorganisasi, dan Kelompok Geng. Penglompokan sosial ini terjadi karena adanya perbedaan antar siswa, baik di tingkat intelegensi, status sosial, perbedaan persepsi, kurangnya interaksi satu sama lain, dan sulit menyesuaikan diri dilingkungan. Sehingga, pengelompokan sosial remaja itu terjadi, mereka yang membentuk kelompok biasanya memiliki tingkatan yang sama. Dalam lingkungan sosial, manusia bisa dengan mudah mencapai tujuan, baik tujuan kelompok maupun tujuan hidup tiap individu untuk memilih jenjang karir yang akan diambil tiap individu di dalam kelompok tersebut dimasa yang akan datang. Dampak negatifnya tentu saja, dengan sikap, perilaku, komunikasi atau tindakan lainnya di lingkungan sosial yang kurang tepat, dapat menimbulkan permasalahan yang beragam, baik yang sederhana sampai yang kompleks. Masa sekolah adalah periode dimana siswa memperluas jangkauan kehidupan sosialnya bersama teman sebayanya yang tidak diperoleh siswa dari lingkungan keluarganya. Melalui lingkungan itulah anak mulai mengenal dunia sekitarnya dan pola pergaulan hidup yang berlaku sehari-hari; melalui lingkungan itulah anak mengalami proses sosialisasi awal (Soerjono, 2004).

Dari pemahaman mengenai kelompok sosial yang ada di dalam lingkup sekolah yang tidak hanya memiliki dampak buruk namun ada dampak baiknya bagi pemilihan karir anggota kelompok atau bisa disebut teman sebaya yang masuk di dalam kelompok sosial itu dan berdasarkan data yang diperoleh peneliti ketika melaksanakan observasi awal, peneliti juga mendapatkan beberapa data dan juga pemahaman dari guru Bimbingan dan Konseling di sekolah tersebut mengenai adanya pengaruh konformitas teman sebaya dalam membentuk pemilihan karir siswa. Hal ini ditunjukkan dengan kemunculan keinginan beberapa siswa yang sama 
dengan salah satu anggota dalam kelompoknya bermain di sekolah, siswa tersebut memiliki keinginan yang sama dalam pemilihan karir.

Dalam hal ini yang menjadi fokus adalah perencanaan karir siswa yang ditinjau dari berbagai faktor. Adapaun beberapa faktor yang perlu diketahui menurut para ahli yaitu: : (1) meningkatkan kesadaran diri (selfawarenes) dan pemahaman diri (self understanding); (2) mencapai kepuasan pribadi (personal satisfaction); (3) mempersiapkan diri pada penempatan yang memadai (adequate placement) dalam berkarir; (4) mengefisienkan waktu dan usaha yang dilakukan dalam berkarir. Dengan dikuasainya setiap indikator yang baik maka diharapkan siswa dapat merencanakan karirnya dengan baik.

\section{Metode}

Penelitian ini menggunakan metode angket (kuisioner), kuisioner merupakan teknik pengumpulan data yang dilakukan dengan cara memberi seperangkat pertanyaan atau pernyataan tertulis kepada responden untuk dijawab (Sugiyono, 2013). Alat pengumpul data tersebut berupa angket perencanaan karir, dan kuisioner angket konformitas teman sebaya yang dikembangkan berdasarkan kajian teori.

Teknik sampel yang digunakan dalam penelitian ini adalah teknik cluster random sampling karena populasi yang diteliti oleh membagi populasi menjadi beberapa kelompok yang terpisah yang disebut sebagai cluster. Dari beberapa cluster ini diambil beberapa sampel yang dipilih secara random atau acak. Menurut Sugiyo (2012) cluster sampling adalah teknik yang digunakan untuk menentukan sampel bila obyek yang akan diteliti atau sumber data sangat luas. Untuk pengambilan jumlah sampel, peneliti menggunakan 116 siswa yang dipilih dari kelas VII yang berjumlah 2 kelas dan dari kelas IX yang berjumlah 2 kelas dengan total siswa dari dua angkatan sebanyak 463 siswa.

\section{Hasil}

Deskripsi hasil penelitian mengenai hubungan antara konformitas teman sebaya dengan perencanaan karir pada siswa SMP Negeri 3 Kota Mageang dapat dilihat sebagai berikut; 
Tabel 1

Perencanaan Karir Siswa SMP Negeri 3 Kota Magelang

\begin{tabular}{cccc}
\hline Interval Persen & Kriteria & Frekuensi & Persentasi \\
\hline $81.25 \%-100 \%$ & Sangat Baik & 6 & $5.17 \%$ \\
$62.5 \%-81.25 \%$ & Baik & 93 & $80.17 \%$ \\
$43.75 \%-62.5 \%$ & Tidak Baik & 17 & $14.66 \%$ \\
$25 \%-43.75 \%$ & Sangat Tidak Baik & 0 & $0.00 \%$ \\
Jumlah & 116 & $100 \%$ \\
Tertinggi & \multicolumn{2}{c}{$86.3 \%$} \\
Terendah & \multicolumn{2}{c}{$48.0 \%$} \\
Simpangan Baku & \multicolumn{2}{c}{$7.8 \%$} \\
Rata-rata & \multicolumn{2}{c}{$70.8 \%$} \\
Kriteria & \multicolumn{2}{c}{ Baik }
\end{tabular}

Berdasarkan Tabel 1 dapat diketahui bahwa perencanaan karir siswa di SMP Negeri 3 Kota Magelang rata-rata masuk dalam kriteria baik atau tinggi.

Kemudian untuk melihat pengaruh dari konformitas terhadap teman sebaya disebut dengan kecenderungan berperilaku sama dengan orang lain akibat adanya tekanan individu atau kelompok. Hasil penelitian mengenai konformitas teman sebaya pada siswa SMP Negeri 3 Kota Magelang dapat dilihat pada Tabel 2 sebagai berikut;

\section{Tabel 2}

Deskripsi Konformitas Teman Sebaya siswa SMP Negeri 3 Kota Magelang

\begin{tabular}{cccc}
\hline Interval Persen & Kriteria & Frekuensi & Persentasi \\
\hline $81.25 \%-100 \%$ & Sangat Baik & 2 & $1.72 \%$ \\
$62.5 \%-81.25 \%$ & Baik & 94 & $81.03 \%$ \\
$43.75 \%-62.5 \%$ & Tidak Baik & 20 & $17.24 \%$ \\
$25 \%-43.75 \%$ & Sangat Tidak Baik & 0 & $0.00 \%$ \\
Jumlah & 116 & $100 \%$ \\
Tertinggi & \multicolumn{2}{c}{$83.4 \%$} \\
Terendah & \multicolumn{2}{c}{$45.0 \%$} \\
Simpangan Baku & \multicolumn{2}{c}{$6.4 \%$} \\
Rata-rata & \multicolumn{2}{c}{$67.8 \%$} \\
Kriteria & \multicolumn{2}{c}{ Baik } \\
\hline
\end{tabular}

Berdasarkan Tabel 2 dapat diketahui bahwa konformitas teman sebaya siswa SMP Negeri 3 Kota Magelang rata-rata masuk dalam kriteria baik atau tinggi.

Penelitian ini bertujuan untuk mengetahui hubungan antara konformitas teman sebaya dengan perencanaan karir di SMP N3 Kota Magelang. Uji Korelasi Pearson Product Moment disajikan dalam tabel 3 sebagai berikut: 
Tabel 3

Uji Hipotesis Statistik Parametris

\begin{tabular}{cccc}
\hline Hubungan & $\mathbf{N}$ & $\mathbf{R x y}$ & $\mathbf{P}$ \\
\hline $\begin{array}{c}\text { Konformitas Teman Sebaya - } \\
\text { dengan Perencanaan Karir }\end{array}$ & 116 & 0,559 & 0,000 \\
\hline
\end{tabular}

Berdasarkan tabel 3 dapat dilihat terdapat hubungan yang positif antara konformitas teman sebaya dengan perencanaan karir $(r=0,559, \mathrm{p}<0,000)$. Dari hasil pengujian. Selanjutnya, diketahui correlation coefficient (koefisien korelasi) sebesar 0,559, maka nilai ini menandakan besar hubungan antara konformitas teman sebaya dengan perencanaan karir.

\section{Pembahasan}

Berdasarkan hasil analisis data untuk mengetahui hubungan antara konformitas teman sebaya dengan perencanaan karir dapat diketahui bahwa ada hubungan positif dan sangat signifikan antara konformitas teman sebaya dengan perencanaan karir pada siswa SMP Negeri Tiga kota Magelang. Temuan penelitian ini mendukung penelitian terdahulu yang dilakukan oleh, Alamiarti (2015), Istiqomah, Lilik Sri Hariani, dan Affan Afian (2017), dan Kristiono (2018).

Adanya hubungan antara konformitas teman sebaya dengan perencanaan karir dalam penelitian ini dapat dijelaskan berdasarkan hasil analisis data yang diperoleh yaitu, semakin tinggi tingkat intensitas konformitas teman sebaya maka semakin tinggi pula tingkat perencanaan karir siswa, sebaliknya jika semakin rendah tingkat intensitas konformitas teman sebaya maka semakin rendah pula tingkat perencanaan karir siswa. Konformitas teman sebaya sendiri mendorong perubahan perilaku dan sikap individu agar sesuai dengan norma yang ada untuk menghindari penolakan agar dapat diterima sebagai anggota kelompok, dan perubahan tersebut sebagai hasil dari tekanan kelompok yang nyata ataupun hanya sebatas imajinasi.

Hal ini juga didukung oleh Gottman \& Parker (dalam Papalia, 2008) bahwa persahabatan memberikan hubungan yang hangat, dekat dan saling percaya dengan individu yang lain (teman sebayanya). Oleh karena itu, hubungan yang dekat bersama atas dasar rasa percaya dengan teman sebayanya akan mendorong individu untuk mengungkap dirinya sendiri untuk lebih membuka dirinya dan mengambil keputusannya untuk menjalani dan memilih karirnya.

Pengambilan keputusan karir siswa di SMP Negeri Tiga Kota Magelang ini memang memiliki minat di bidang karir yang dipilih oleh kebanyakan teman dalam satu kelompoknya dikarenakan saat bersama temannya siswa mendapatkan arahan untuk memutuskan jurusan pemilihan karir yang harus di pilihnya. Hal tersebut didukung oleh Dalyono (2010), peran teman sebaya yaitu dimana para remaja bergaul dapat mempengaruhi dan mengarahkan minat seseorang terhadap suatu objek seperti mengarahkan pengambilan keputusan karir dalam berbagai hal. Santrock (2007) peranan teman sebaya dalam proses perkembangan sosial anak 
antara lain berpengaruh dalam stimulasi berfikir untuk merencanakan pemilihan karirnya, konformitas teman sebaya juga sebagai salah satu sumber dukungan yang kuat dalam pengambilan keputusan karir, serta dalam fungsi perbandingan sosial siswa dapat melihat dari teman-temannya arah perencanaan karir seperti apa yang harus diambil dalam hal ini konformitas teman sebaya berperan penting dalam perencanaan karir siswa.

Dari hasil penelitian mengenai hubungan antara konformitas teman sebaya dengan perencanaan karir pada siswa SMP Negeri Tiga Kota Magelang, dapat disimpulkan bahwa konformitas teman sebaya menjadi alasan siswa untuk mempertimbangkan dirinya dalam menentukan pemilihan karirnya, meninjau dampak yang ditimbulkan dari adanya peran konformitas teman sebaya terhadap perencanaan karir siswa keterkaitannya dengan bimbingan dan konseling sesuai dengan fungsi bimbingan dan konseling yaitu dengan adanya bimbingan dan konseling mampu memberikan pemahaman dan pencegahan, serta pengentasan yang diharapkan dapat meningkatkan tingkat konformitas teman sebaya dalam merencanakan karir.

\section{Simpulan}

Berdasarkan hasil penelitian dan pembahasan di atas mengenai Hubungan antara Konformitas Teman Sebaya dengan Perencanaan Karir dapat diambil simpulan bahwa tingkat konformitas teman sebaya dilihat memiliki faktor yang berperan penting dalam adanya teman sebaya masuk dalam kategori baik. Kemudian ada hubungan antara konformitas teman sebaya dengan perencanaan karir pada siswa SMP Negeri Tiga Kota Magelang, Semakin tinggi tingkat intensitas konformitas teman sebaya maka semakin tinggi pula tingkat perencanaan karir siswa, sebaliknya jika semakin rendah tingkat intensitas konformitas teman sebaya maka semakin rendah pula tingkat perencanaan karir siswa.

\section{Daftar Pustaka}

Alamiarti, Kharisma Ayu. 2015. Hubungan Antara Konformitas Teman Sebaya Dan Harga Diri Dengan Pengambilan Keputusan Karir Pada Siswa Kelas XII SMK Karya Rini YHI Kowani Yogyakarta. Yogyakarta: Universitas Negeri Yogyakarta

Dalyono, M. 2010. Psikologi Pendidikan. Jakarta: Rineka Cipta.

Fatresi, Mei Saroh Mega. 2017. Hubungan Antara Konformitas Dan Harga Diri Dengan Pengambilan Keputusan Karir Pada Mahasiswa Psikologi Semester 8 Universitas Islam Negeri Maulana Malik Ibrahim Malang. Malang: Universitas Islam Negeri Maulana Malik Ibrahim Malang

Gottman, J.M., \& Parker, J.G. 1987. The Importance of Friendship. [Online]. Tersedia: http://www.deanza.edu/faculty/cruzmayra/cd10hwl lassignments activities.pdf [27 Februari 20011]. 
Santrock, John W. 2007. Perkembangan Anak. Jilid 1 Edisi kesebelas. Jakarta: PT. Erlangga.

Kristiono, Wahyu Sri. 2018. Peran Kelompok Teman Sebaya Dalam Menentukan Pengambilan Keputusan Karir Pada Siswa Kelas XI Di SMK Negeri 7 Yogyakarta. Yogyakarta

Munandir. 1996. Program Bimbingan dan Konseling di Sekolah. Jakarta: Depdikbud

Jauch, L.R. dan Glueck, W.R. 1997. Manajemen Strategis dan Kebijakan Perusahaan, Edisi IV, Jakarta: Erlangga.

Soekanto, Soerjono. 2004. Sosiologi Keluarga. Jakarta: PT Rineka Cipta.

Sugiyono. 2012. Memahami Penelitian Kualitatif. Bandung: Alfabeta.

2013. Metode Penelitian Pendidikan. Bandung: Alfabeta. 